\title{
KUALITAS PEMBELAJARAN MAHASISWA SELAMA KULIAH ONLINE
}

\author{
Oleh \\ Prama Widayat \\ Universitas Lancang Kuning-Pekanbaru \\ pramawidayat@unilak.ac.id
}

diterima 08 Pebruari 2021, direvisi 16 Pebruari 2021, diterbitkan 28 Pebruari 2021

\begin{abstract}
Between the world of education and technology cannot be separated because these two sides are interrelated, student learning can be done online and offline by looking at the situation and conditions. The abilities and limitations they have are also different, so there is a need for a policy by dividing the zones in implementing online lectures based on the quality of the internet network owned by each region where the student comes from. The quality of the learning process can be seen from the quality of the lecturers who teach and the learning media used, especially in online learning everything has to adjust. The problem of an unstable internet network and lecturers who are not fully ready to teach online are the main problems in online learning. So that is the importance of dividing 3 zones for the application of online lectures, zone 1 network is strong and stable can study online, zone 2 network is less strong and stable, online and offline lectures and zone 3 networks are not yet available so offline lectures are conducted
\end{abstract}

\section{Keywords: Quality, Online, Learning Media}

\section{PENDAHULUAN}

Pandemi yang terjadi sejak Maret 2020 merubah sendi-sendi kehidupan seperti ekonomi dan pendidikan, banyak yang tidak siap dan ada juga yang siap menghadapi perubahan ini, walaupun pihak yang sudah siap menerima perubahan belum bisa dikatakan $100 \%$.

Tidak ada satupun pihak yang menyangka bahwa wabah yang berasal dari negara china akan menyebar secara masif diberbagai negara dan mengacaukan pola kehidupan manusia. Sektor ekonomi dan pendidikan adalah yang paling merasakan dampaknya. Khususnya bidang pendidikan formal yang selama ini mengandalkan perkuliahaan tatap muka (offline) didalam kelas sehingga mau tidak mau, suka tidak suka semuanya harus beradaptasi (Sztejnberg, 2006:504-505) dengan class online (Quinn, 2014:53). 
Awalnya perkuliahan masih dilakukan didalam kelas, tetapi melihat situasi yang semakin masif dan jumlah korban semakin bertambah maka diputuskan sejak maret 2020 semua perkuliahaan dialihkan menggunakan media online. Khususnya perguruan tinggi yang ada di Indonesia, sebagian besar tidak siap dengan kondisi ini, banyak yang masih mengandalkan perkuliahan offline dan tidak banyak yang menyangka akan terjadi perubahan drastis seperti sekarang. Bisa dikatakan bahwa hanya perguruan tinggi tertentu saja yang siap dengan perkuliahan online.

Banyak keluhan datang dari dosen dan juga mahasiswa, berbagai masalah muncul kepermukaan seperti kuota paket internet yang mahal, jaringan internet yang tidak merata, masih untung mereka yang tinggal diperkotaan dengan jaringan yang cukup stabil dan nasib kurang baik bagi mahasiswa yang berasal dari daerah yang jauh dari jangkauan internet. Sehingga mereka harus mencari lokasi yang lebih tinggi untuk mendapatkan jaringan internet yang stabil demi mengikuti perkuliahan.

Belum lagi mengenai materi perkuliahaan yang tidak semuanya bisa dijelaskan dengan menggunakan media online karena memang harus dilakukan praktek laboratorium. Bagi program studi yang tidak membutuhkan laboratorium tentunya bisa menyesuaikan dengan mendapatkan modul dari dosen pengajar.

Terkadang materi yang diberikan tidak bisa langsung dipahami oleh mahasiswa, untuk perkuliahan didalam kelas saja mereka butuh waktu juga untuk memahaminya, apalagi saat sekarang mereka lebih banyak belajar mandiri dirumah, berbeda dengan kuliah tatap muka langsung dimana mereka bisa mendengarkan dengan baik karena ketika mahasiswa mampu mendengarkan secara langsung daya serapnya akan lebih maksimal (Nayar, 2020:134-135) dibandingkan secara online.

Banyaknya tugas yang diberikan oleh para dosen mata kuliah sehingga mahasiswa terbebani dengan tugas tersebut, tidak sedikit dari mereka yang mengeluh dengan waktu yang sempit sementara tugas yang harus diselesaikan bisa 2 atau 3 paper dari mata kuliah yang berbeda.

Tidak jarang mahasiswa yang pulang kekampung halaman selama perkuliahan online, mereka harus membantu ekonomi keluarga dengan bekerja membantu orang tua diladang ataupun dikebun, sehingga mereka juga bekerja sambil mendengarkan perkuliahan dan tentunya ini tidak maksimal. Hal ini mereka lakukan agar tidak absen ketinggalan perkuliahan pada mata kuliah yang diikuti.

Dari sisi dosen yang sebenarnya terdapat berbagai prolematika diantaranya ketika mengajar secara online dari rumah, tidak terlalu konsentrasi karena dibarengi dengan tugas rumah, termasuk mereka yang punya balita dan tentunya akan mengganggu mereka dalam mengajar. Ketika kuliah offline mereka bisa membagi waktu antara mengajar dan dirumah, ketika mereka mengajar tatap muka dikampus tentunya mereka lebih fokus karena anak ditinggal dirumah, namun saat kuliah online dari rumah tidak bisa terlalu konsentrasi karena waktu dirumah seharusnya bermain dengan anak akan terganggu dengan jadwal kuliah.

Ketika dosen tidak konsentrasi dalam mengajar maka tentunya materi yang diterima oleh mahasiswa tidak maksimal, ada suasana kelas yang tidak bisa digantikan dengan perkuliahan online. Ketika perkuliahan dalam kelas, sang dosen bisa memperhatikan prilaku mahasiswa satu per satu sehingga tingkat pengawasan cukup tinggi (Raza, 2014:10), berbeda dengan kuliah online yang terkadang tidak nampak wajah karena gangguan sinyal atau lainnya.

Dalam perkuliahaan tatap muka, dosen bisa sambil menerapkan nilai moral kepada mahasiswa seperti datang tepat waktu untuk mengajarkan mahasiswa disiplin, pakaian yang digunakan juga harus kemeja sedangkan selama kuliah online untuk pakaian tidak diatur, tidak jarang ada yang menggunakan kaos.

Bahkan ada juga dosen yang tidak paham menggunakan media online seperti zoom, google clasroom dan lainnya. Pada 
akhirnya penilaian selama kuliah online lebih longgar dan nilai objektifitas menjadi berkurang, lebih banyak pada sisi kemanusiaan. Seperti kasian mahasiswa yang jauh dari kota, mereka untuk kuliah saja kesulitan mendapatkan sinyal, mereka harus bekerja membantu ekonomi keluarga dikampung sehingga untuk diberikan nilai rendah sangat tidak manusiawi. Hal-hal non teknis seperti inilah terkadang yang menurunkan kualitas pembelajaran.

\section{METODE}

Metode yang digunakan adalah dengan menggunakan metode penelitian deskriptif kualitatif, dengan melakukan pengisian kuisioner dan juga wawancara secara singkat. Diambil secara acak sebanyak 200 mahasiswa yang ada dikota Pekanbaru. Metode kualitatif dipilih karena dinilai lebih tepat untuk menggali jawaban terhadap studi kasus (case study), dimana problem perkuliahan online merupakan sebuah kasus yang perlu digali lebih dalam dan bukan sekedar angka-angka statistik.

Dimana studi kasus ini butuh eksplorasi mendalam terhadap sebuah kejadian, proses, aktifitas terhadap satu atau lebih orang dengan mengumpulkan data secara berkesinambungan. Hal ini relevan dengan perkuliahan online yang sudah berjalan 1 tahun atau 2 semester sejak Maret 2020 sampai dengan Januari 2021.

\section{PEMBAHASAN}

Mereka diminta untuk memberikan jawaban yang objektif tentang kualitas pembelajaran online yang selama ini mereka jalankan, apakah materi yang mereka terima dan pahami itu sama dengan perkuliahaan tatap muka, dan beberapa pertanyaan lainnya.

\subsection{Pemahaman materi perkuliahan}

Kesuksesan sebuah pembelajaran adalah munculnya pemahaman dari mahasiswa sehingga mata kuliah yang mereka ambil tersebut betul-betul mampu diserap dengan baik. Pembelajaran yang efektif bukan hanya sekedar pandai menghafal apa yang diberikan oleh dosen ataupun pengajar tetapi mampu menggunakan waktu perkuliahan dengan mendapatkan point-point penting.

Bagi sebagian mahasiswa, perkuliahan dengan sistem online masih dianggap asing dan hal yang baru karena selama ini perkuliahan masih dilakukan secara konvensional didalam kelas. Dengan kondisi saat yang memaksa perkuliahan dilakukan secara online, tidak sedkit mahasiswa yang mengatakan bahwa kurang memahami materi yang diberikan saat perkuliahaan online berbeda dengan perkuliahan didalam kelas bahwa mereka lebih menikmati karena adanya interaksi langsung.

Tidak bisa dipungkiri bahwa interaksi langsung itu memberikan nilai lebih dalam sebuah pembelajaran, dimana hal ini tidak bisa dirasakan mahasiswa ketika melalui kuliah online. Sebagian mahasiswa mungkin saja tidak mengambil pusing untuk hal ini karena bagi mereka yang penting kuliah tetapi bagi mahasiswa yang betul-betul ingin mendapatkan ilmu demi masa depannya maka mereka merasakan ada perbedaan yang signifikan.

Karena beberapa dosen hanya memberikan modul kepada mahasiswa dan diminta pelajari sendiri, setelah itu diberikan tugas dan dikumpulkan dalam waktu tertentu antara 3 hari sampai 7 hari kalender. Bahkan ada juga dosen yang hanya beberapa kali melaksanakan kuliah online dan setelah itu langsung ujian, dimana mahasiswa hanya diminta untuk membaca materinya dengan alasan dosen tersebut sedang ada kegiatan dan lainnya.

Mahasiswa mau protes tidak berani karena takut nantinya nilai mereka yang akan menjadi ancaman, dengan kata lain mereka ikut saja apa yang diperintahkan oleh dosen mereka. Praktek-praktek seperti ini yang dilakukan oleh oknum dosen, akan merusak pola pendidikan. Bagaimana mungkin akan menghasilkan lulusan yang berkualitas jika proses yang dilakukan tidak sesuai dengan standar.

Proses pembelajaran yang benar akan menghasilkan kualitas yang mumpuni (Naeve, 2008:13; Bawden, 2002:137-138; Dealtry, 2009:163-164) dan bukan sekedar 
nilai diatas kertas, buat apa nilai tinggi tetapi tidak memiliki skill. Bagaimana mungkin kita berbicara skill jika proses didalam kelas tidak berjalan dengan baik (Patel, 1995:22-23; Erdemci, 2020; Fredberg, 2011:158-159). Jadi ini adalah rangkaian ataupun simbiosis yang tidak bisa dipisahkan. Karena didalam dunia kerja nantinya mereka dituntut untuk menunjukkan kemampuan dan juga harus bisa berinovasi (Buckler, 1998:20-22; Docherty, 2009:136-137; Blessinger 2013:8-10)

\subsection{Media pembelajaran}

Jian (2009:844-845) efektifitas kelas online tergantung kepada media yang digunakan karena dunia pendidikan berkembang dengan pesat dengan penggunaan teknologi era digital (Crystal, 2020:6; Wilkin, 2013:99-101). Beberapa media yang digunakan untuk kuliah online seperti blended learning (Nayar, 2020:10-11; Chowdhury, 2019:11-12), media sosial (Pals Svendsen, 2012:84-85).

Media pembelajaran seharusnya bukan hanya dikelas, bisa saja dilakukan diruang terbuka hijau, kunjungan perusahaan, ataupun lainnya. Namun karena pandemi covid-19 itu tidak bisa dilakukan dan dialihkan kepada pembelajaran online dengan menggunakan zoom, google classroom, blended learning dan sejenisnya.

Paling dominan digunakan adalah zoom dan juga google classroom karena dinilai lebih simple dan mudah. Perlu diperhatikan dalam pembelajaran online yang menjadi syarat utamanya adalah jaringan internet yang memadai. Tidak lupa juga handphone dan serta laptop disediakan untuk memberikan dukungan selama proses belajar mengajar.

Permasalahannya adalah tidak semua mahasiswa mampu membeli handphone yang bisa digunakan sebagai sarana pembelajaran online, belum lagi kita bicara kebutuhan laptop. Maka sangat tidak adil rasanya jika mereka tidak dapat mengikuti perkuliahan daring karena kebijakan dunia pendidikan, seharusnya ini dikaji secara matang sebelum diterapkan. Perlu adanya solusi bahwa bisa dilakukan belajar kelompok, dimana 1 handphone atau laptop bisa digunakan oleh beberapa mahasiswa dengan catatan mereka tinggal berdekatan.

Namun mereka berdomisili pada daerah yang berbeda-beda, maka sekiranya kampus mampu memberikan fasilitas kepada mahasiswa dengan membentuk kelompok belajar dan diharapkan mahasiswa tidak pulang kampung, mereka tetap menjaga protokol kesehatan dengan berada di kost ataupun kontrakan dan mengurangi kegiatan diluar rumah. Intinya adalah adanya kebijakan yang humanis bagi mahasiswa dan bukan sekedar menerapkan kuliah daring (online).

\subsection{Kualitas dosen mengajar}

Hammerness

(2015:267-270)

menyatakan bahwa kualitas dosen pengajar menentukan mutu dikelas sehingga mahasiswa yang menerima materi, juga punya kualitas SDM yang mumpuni dari transfer pengetahuan selama dalam pembelajaran (Widayat, 2018:70-73). Tujuan mahasiswa ingin kuliah adalah ingin mendapatkan ilmu maka dari itu mahasiswa mau dosen yang berkualitas (Voss, 2006:233-234; Voss, 2009:168-169) dan profesional (Wardoyo, 2019:11-12; Khalsiah, 2018:24; White, 2008:131-132; Farrugia, 1996:29-30).

Kualitas pendidikan itu terletak pada dosen dan juga mahasiswa (BarandiaranGaldós, 2012:105-106; Mattah 2018: 49). Dosen bukan hanya mengajar didalam kelas tetapi juga mampu berkomunikasi diluar kelas (Nikhoma, 2018:329; Meixner, 2009:196197; Lin, 2013:144-145; Liu, 2011:16-17) karena tidak semua bisa dipahami didalam kelas, kadang mahasiswa juga butuh konsultasi diluar kelas untuk membahas berbagai topik termasuk juga diluar materi yang diberikan didalam kelas seperti tentang bisnis dan memulai usaha (Thom, 2017:15) sambil kuliah, dunia kerja, trik untuk sukses dalam karir. Artinya ini ada feedback yang diberikan oleh mahasiswa (Tóth, 2017:417), untuk itu dosen juga wajib menguasai bidang tertentu dan juga punya wawasan luas sebagai tempat bertanya mahasiswa. Inilah pentingnya dosen sebagai sumber daya manusia (SDM) yang unggul untuk mencetak 
generasi yang unggul dan mampu bersaing muli dri

Era teknologi informasi atau disebut era 4.0 membuat seorang dosen juga harus menguasai teknologi, minimal yang berkaitan dengan sarana pendukung dalam proses pembelajaran. Jangan sampai ada dosen yang gagap teknologi (gaptek), karena ini akan menjadi faktor penghambat terwujudnya pendidikan yang profesional.

Memang terlintas pembicaraan dikalangan dosen bahwa dahulu tidak serumit ini cara kita mengajar, memang iya karena dahulu kala hanya datang, absen, masuk kelas dan pulang. Perubahan berlangsung cepat dan dinamis, menuntut seorang dosen untuk up grade ilmu dan wawasan. Kedepan tidak ada yang mengetahui perubahan apalagi yang akan terjadi. Namun yang pasti bahwa perubahan itu akan selalu terjadi (Macarov, 1988:90-95), jangan malu untuk mengakui kekurangan karena dengan itu kita terus belajar. Tidak ada dosen yang berhenti untuk belajar walaupus sekelas profesor, tuntutan dunia kerja dan juga dunia bisnis harus diikuti dengan kualitas dunia pendidikan. Berkualitasnya sebuah institusi perguruan tinggi bisa dilihat dri akreditasinya (Widayat, 2018:204-205) tergantung kepada kualitas SDM dosennya. Untuk itu perguruan tinggi harus membangun persepsi yang positif (Widayat, 2020:105). Jika ada dosen yang tidak berkualitas maka disinilah peran penjaminan mutu (Suci, 2017:219-220) yang ada disebuah perguruan tinggi untuk melakukan evaluasi dan pembinaan.

\subsection{Perlukah kuliah online}

Kuliah online memang dibutuhkan untuk mendukung kemajuan bidang teknologi, karena pendidikan dan teknologi adalah dua sisi yang tidak bisa dipisahkan. Tetapi hal ini tidak bisa dipukul rata, untuk mendukung online class maka perlu juga dipersiapkan perangkat utama yaitu jaringan internet yang sudah merata dari sabang sampai merauke diseluruh wilayah Indonesia.

Jika perangkat ini belum memadai maka harus ada pembagian zona, dimana pada zona yang sudah dilengkapi dengan jaringan internet yang kuat dan stabil serta murah maka bisa melaksanakan kuliah online. Berikut pembagian zona yang tepat, dimana kami membagi 3 zona :

Zona 1 : Jaringan kuat dan stabil

Zona 2 : Jaringan belum kuat dan stabil

Zona 3 : Jaringan belum tersedia

Pada zona 1 dapat dilaksanakan kuliah online sesuai dengan keinginan karena mereka sudah didukuang dengan jaringan yang kuat dan stabil. Zona 2 dapat menggabungkan perkuliahan online dan offline karena jaringan yang tersedia belum kuat dan belum stabil sehingga jika dipaksakan dengan kuliah online maka hasilnya tidak akan maksimal karena kualitas pembelajaran yang tidak baik.

Zona 3 masih belum tersedia jaringan internet sehingga tidak perlu dilaksanakan kelas online, dimana kelas offline harus dilaksanakan karena terlalu memaksa kuliah online sementara situasi dan kondisi yang tidak tepat maka hasilnya akan jelek.

Inilah yang perlu dilakukan jika memang menginginkan kuliah online dilaksanakan, wilayah Indonesia yang luas tidak bisa disamakan dengan kondisi negaranegara lain yang sudah siap menghadapi online class.

\section{KESIMPULAN}

Pembelajaran secara online selama pandemi covid-19 tidak bisa disamakan diseluruh wilayah indonesia karena ada wilayah yang belum siap terutama untuk jaringan internet, belum lagi quota internet yang mahal walaupun ada paket gratis dari pemerintah tetapi tidak maksimal mengingat jumlah mahasiswa yang cukup banyak dan tersebar dari sabang hingga merauke.

Terlalu memaksakan kuliah online sementara mahasiswa yang ada dipelosok dan jauh dari jangkauan internet kesulitan untuk mengikuti perkuliahan maka ini adalah 
bentuk kezoliman karena setiap anak bangsa berhak mendapatkan pendidikan yang layak.

Untuk itu perlu dilakukan pembagian zona dalam penerapan kuliah online, jangan hanya zona darurat covid. Perlu dikaji ulang kebijakan kuliah online karena terlalu banyak keluhan dari mahasiswa dan juga dosen. Dunia pendidikan jangan selalu menjadi korban dalam ujicoba kebijakan karena mutu dan masa depan anak bangsa tergantung bagaimana sebuah bangsa membangun sebuah proses pendidikan yang adil sesuai dengan kebutuhannya dan bukan hanya sekedar untuk kepentingan pihak tertentu.

\section{DAFTAR PUSTAKA}

Barandiaran-Galdós, M., Barrenetxea Ayesta, M., Cardona-Rodríguez, A., José Mijangos del Campo, J., \& OlaskoagaLarrauri, J. 2012. What do teachers think about quality in the Spanish university? Quality Assurance in Education, 20(2), 91-109.

Bawden, R., \& Zuber-Skerritt, O. 2002. The concept of process management. The Learning Organization, 9(3), 132-139.

Blessinger, P., \& Wankel, C. 2013. Creative Approaches in Higher Education: An Introduction to Using ClassroomMediated Discourse Technologies. Cutting-Edge Technologies in Higher Education, 3-16

Buckler, B. 1998. Practical steps towards a learning organisation: applying academic knowledge to improvement and innovation in business processes. The Learning Organization, 5(1), 1523

Crystal Fulton, 2020. Collaborating in online teaching:inviting e-guests to facilitatelearning in the digital environment. Information and Learning Sciences.

Dealtry, R. 2009. The design and management of an organisation's lifelong learning curriculum. Journal of Workplace Learning, 21(2), 156-165

Docherty, P., Kira, M., \& (Rami) Shani, A. B. 2009. Organizational development for social sustainability in work systems.
Research in Organizational Change and Development, 77-144

Erdemci, H., \& Karal, H. 2020. Examination of instructors' experiences for the use of learning analytics. The International Journal of Information and Learning Technology,

Chowdhury, Faieza. 2019, Blended learning: how to flip theclassroom at HEIs in Bangladesh?, Journal of Research in InnovativeTeaching \& Learning.

Farrugia, C. (1996). A continuing professional development model for quality assurance in higher education. Quality Assurance in Education, 4(2), 28-3

Fredberg, T., Norrgren, F., \& (Rami) Shani, A. B. 2011. Developing and Sustaining Change Capability VIA Learning Mechanisms: A Longitudinal Perspective on Transformation. Research in Organizational Change and Development, 117-161.

Hammerness, K., \& Klette, K. 2015. Indicators of Quality in Teacher Education: Looking at Features of Teacher Education from an International Perspective. International Perspectives on Education and Society, 239-277

Jian, Q. 2019. Effects of digital flipped classroom teaching method integrated cooperative learning model on learning motivation and outcome. The Electronic Library, 37(5), 842-859

Khalsiah, Nur Asma and Marina. 2018. The Efforts of Improving the Professionalism of Lecturers towards the Presentation and Change of KKNI within the University Environment in Aceh. Emerald Reach Proceedings Series Vol. 1 pp. 19-25

Lin, P., Krishnan, S., \& Grace, D. (2013). The Effect of Experience on Perceived Communication Skills: Comparisons between Accounting Professionals and Students. Advances in Accounting Education, 131-152

Liu, J., Wang, W., \& Cao, K. (2011). Leader political skill and team performance: $a$ 
moderated mediation model. Nankai Business Review International, 2(1), 5 22

Macarov, D. (1988). Quitting Time: The End of Work. International Journal of Sociology and Social Policy, 8(2/3/4), 1-181

Mattah, P. A. D., Kwarteng, A. J., \& Mensah, J. 2018. Indicators of service quality and satisfaction among graduating students of a higher education institution (HEI) in Ghana. Higher Education Evaluation and Development, 12(1), 36-52

Naeve, A., Sicilia, M., \& Lytras, M. D. 2008. Learning processes and processing learning: from organizational needs to learning designs. Journal of Knowledge Management, 12(6), 5-14.

Nayar, B., \& Koul, S. 2020. Blended learning in higher education: a transition to experiential classrooms. International Journal of Educational Management

Nayar, Burna and Surabhi Koul. 2020. The journey from recallto knowledgeA study of two factors-structured doodlingand note-taking on a student's recall ability. International Journal ofEducational Management Vol. 34 No. 1, pp. 127-138

Nkhoma, C. A., Thomas, S., Nkhoma, M. Z., Sriratanaviriyakul, N., Truong, T. H., \& Vo, H. X. (2018). Measuring the impact of out-of-class communication through instant messaging. Education + Training, 60(4), 318-334.

Meixner, W. F., Bline, D., Lowe, D. R., \& Nouri, H. (2009). An examination of business student perceptions: the effect of math and communication skill apprehension on choice of major. Advances in Accounting Behavioral Research, 185-200

Patel, N. V. 1995. Application of soft systems methodology to the real world process of teaching and learning. International Journal of Educational Management, 9(1), 13-23

Pals Svendsen, L. 2012. How Social Media Enhanced Learning Platforms
Challenge and Motivate Students to Take Charge of their Own Learning Processes. Increasing Student Engagement and Retention Using Social Technologies, 57-88.

Quinn, R. E., Heynoski, K., Thomas, M., \& Spreitzer, G. 2014. Co-Creating the Classroom Experience to Transform Learning and Change Lives. Research in Organizational Change and Development, 25-54.

Raza, A., \& Sohaib Murad, H. 2014. Learning in plural cultural context. Journal for Multicultural Education, 8(1), 2-12.

Setiawan, Rony., Ariesya Aprillia and Nonie Magdalena, 2020, Analysis of antecedent factors inacademic achievement andstudent retention. Asian Association of OpenUniversities Journal Vol. 15 No. 1, 2020 pp. 37-47

Sztejnberg, A., \& Finch, E. F. 2006. Adaptive use patterns of secondary school classroom environments. Facilities, 24(13/14), 490-509.

Suci, afred. 2017. Penjaminan mutu perguruan tinggi : dilema politik organisasi dan urgensi penggunaan profesional eksternal. Jurnal Penjaminan Mutu. Volume 3 Nomor 2 Agustus pp 215-222 pp.

Thom, M. 2017. Arts entrepreneurship education in the UK and Germany. Education + Training, 59(4), 406-426

Tóth, Z. E., Andor, G., \& Árva, G. 2017. Peer review of teaching at the Budapest University of Technology and Economics Faculty of Economic and Social Sciences. International Journal of Quality and Service Sciences, 9(3/4), 402-424

Voss, R., \& Gruber, T. 2006. The desired teaching qualities of lecturers in higher education: a means end analysis. Quality Assurance in Education, 14(3), 217-242

Voss, R. 2009. Studying critical classroom encounters. Quality Assurance in Education, 17(2), 156-173 
Wardoyo, Cipto., Aulia Herdiani., Nurdian Susilowati., Muhammad Syahril Harahap. 2019. Professionalism andprofessionalization of early stageteachers in higher education Journal of Applied Research inHigher Education.

Widayat, Prama. 2018. Between cost chep prices and increasing high quality educational university in pekanbaru city. Jurnal Penjaminan Mutu. Volume 4 Nomor 1 Februari pp. 6775.

Widayat, Prama. 2018. Peran akreditasi dalam menarik minat mahasiswa memilih perguruan tinggi swasta bermutu di Kota Pekanbaru. Jurnal Penjaminan Mutu. Volume 4 Nomor 2 Agustus pp. 99-107
Widayat, Prama. 2020. Persepsi mahasiswa terhadap mutu internal Fakultas Ekonomi Universitas Lancang Kuning. Jurnal Penjaminan Mutu. Volume 6 Nomor 1 Februari pp. 99107

Wilkin, C. L., Rubino, C., Zell, D., \& Shelton, L. M. 2013. Where Technologies Collide: A Technology Integration Model. Cutting-Edge Technologies in Higher Education, 81-106.

White, S. (2008). Using Action Research - To Gauge the Quality of Feedback Given to Student Teachers While on Professional Teaching Practice. Qualitative Research Journal, 8(2), 124-133 